\title{
Mercury in the Diet, Absorption and Bioaccessibility
}

\author{
Najwa Abdullah \\ The University of Jordan, Amman, Jordan \\ Email:najwazitawi@gmail.com
}

How to cite this paper: Abdullah, N. (2020) Mercury in the Diet, Absorption and Bioaccessibility. Open Access Library Journal, 7: e6666.

https://doi.org/10.4236/oalib.1106666

Received: July 26, 2020

Accepted: October 26, 2020

Published: October 29, 2020

Copyright $\odot 2020$ by author(s) and Open Access Library Inc.

This work is licensed under the Creative Commons Attribution International License (CC BY 4.0).

http://creativecommons.org/licenses/by/4.0/

(c) (i) Open Access

\begin{abstract}
Background: The human body is exposed to significant amounts of the potent inorganic mercury $\left(\mathrm{Hg}^{+2}\right)$ or methylmercury $(\mathrm{Me}-\mathrm{Hg})$. The diet is the main route for this exposure; the fish consumption may result in confusion for the crucial benefits of the fish consumption beside the hazardous side of their content of mercuric compounds. The mercuric compounds have different routes of absorption, mostly by the gut through the diet, causing severe health problems via the oxidative stress mechanisms. The diet complexity regarding ingredients and cooking type may affect the bioaccessibility of the present mercuric compounds by several mechanisms, in addition to the protective role of gut microbiota. Method: This review tries to explore the available data and researches, about the mercuric present forms, absorption pathways, toxicity mechanisms and dietary components. Results: As human exposed to several mercury sources, the diet complex composition and preparation negatively affect the mercuric compounds bioaccessibility; including the cooking type, fat content, omega- 3 fatty acids, selenium, glutathione, gut microflora, ethanol content, garlic, onion, tea, coffee, and fruits, via several mechanisms.
\end{abstract}

\section{Subject Areas}

Food Science \& Technology

\section{Keywords}

Mercury, Accessibility, Toxicity, Absorption

\section{Introduction}

Historical accidents resulted from inappropriate use of mercury, caused several disasters. The main route of mercury exposure is the fish based diet, fish diet is 
recommended due to its unique nutritional composition of proteins and significant amounts of the essential omega-3 $\alpha$-linolenic acid (ALA 18:3 n-3) fatty acids, the precursors of the eicosapentaenoic acid (EPA), and docosahexaenoic acid (DHA), the important Prostaglandins and leukotrienes for anti-oxidation mechanisms [1], that have a role to lessen of rate of the cardiovascular diseases and other oxidative stress diseases.

On the other hand, fish contain significant amounts of the toxic heavy metal mercury after marine environment contamination of mercu + ric compounds. Mercury in its different forms: inorganic $\left(\mathrm{Hg}^{+2}\right)$, elemental mercury $\left(\mathrm{Hg}^{0}\right)$, or organic mercury (methylmercury and ethyl mercury) [2].

Exposure to mercuric compounds results in adverse health problems; affects the cardiometabolic syndrome (CMS) biomarkers [3], accumulation in brain [4], liver and kidneys [5], caused by oxidative stress due to its strong ability to bind to the sulfhydryl cysteine terminal in the vital proteins and enzymes [6] [7], mainly disrupt the anti-oxidizing glutathione proteins [4] [8].

All types can be absorbed via the gastrointestinal tract at different rates and different mechanisms [9], simple, facilitated and active diffusion [10] [11] [12], the neutral amino acid L-type transporters (LAT) and the organic anionic transporters (OAT) [5] [9].

Diet complexities have a protection effect for mercury absorption. In vivo, animal studies, showed the lower blood mercury level after exposure to defined dose of the mercuric compounds. Several studies investigate the factors that may affect the mercury bioaccessibility in the gastrointestinal gut. Including: cooking effects [13] [14] [15], fat content [16] [17] [18], omega-3 fatty acids content [19] [20], presence the divalent metals, mainly the selenium [21] [22] [23], protein and glutathione content [4] [8] [19] [21] [24], dietary fibers effect [25] [26] [27] and the gut microflora [28] [29] [30] [31]. Beside the biochemical compounds in garlic and onion [32] [33] [34] [35] [36], ethanol content [37] [38] [39], fruits effect and the antioxidants [40] [41] [42] [43], green tea, black tea and coffee effect [14] [15] [44] [45].

In conclusion, even though human body is exposed to trace toxic amounts of mercury, its absorption depends on several factors including the ethnic, age, physiological status, also its bioaccessibility to absorption may diminish in the presence by several dietary factors present in the diet.

\section{Method}

This review tries to explore the available data and researches, about the mercuric present forms, absorption pathways, toxicity mechanisms and dietary components.

Mercury: It's a heavy metal with known toxicity. Several historical accidents for mercury toxicity took place, due to inappropriate use of mercury. Such as; in construction of Mercury Rivers in mausoleum of Chinese Emperor Qin Shi Huang at $(260-210 \mathrm{BC})$, which results in sudden premature death after mer- 
curic dose consumption [46]. The First Japan Minamata disease (1956), the Second Niigata Minamata Disease (1965), results in severe neurological symptoms after eating fish contaminated from water by mercury waste [47]. Similar symptoms were detected in the Iraq poison grain disaster (1971) after eating bread from wheat treated with mercuric fungicide [48].

Mercury presents mainly in three forms: 1-Elemental mercury $\left({ }^{203} \mathrm{Hg}^{0}\right)$ : It is liquid at room temperature, used in dental amalgams, thermometers, lights and other processes. It is volatile and mainly absorbed through the respiratory tract $(80 \%)$, whereas its absorption through the gastrointestinal tract is negligible. 2-Inorganic mercury $\left(\mathrm{Hg}^{+2}\right)$ : Gastrointestinal absorption of inorganic mercury is relatively poor compared to the organic form (10\% - 30\%). Distributes mainly in the kidneys (by $60 \%-90 \%$ ) and, to a lesser extent, to the liver. The critical effect of inorganic mercury is renal damage. 3-Organic mercury (methylmercury $\mathrm{MeHg}$ andethyl mercury), which bio-accumulates and biomagnifies along the food chain, particularly in the aquatic food chain; long lived carnivorous fish and marine mammals exhibiting the highest contents [49] [50].

Absorption mechanism: Exposure to $\mathrm{Hg}^{+2}$ and $\mathrm{MeHg}$ occurs mainly through diet. Bioaccumulation and magnification of the mercury compounds to several folds more than the source [5] [9].

Several suggested absorption processes through the mammalian intestinal epithelial tissues including:

- Inorganic mercury $\mathrm{Hg}^{+2}$ enters the cells by simple diffusion or through voltage-gated $\mathrm{Na}^{+} \mathrm{K}$ pump cotransporter and $\mathrm{Ca}^{+2}[10]$.

- Passive simple diffusion of neutral mercury amino acid complexes mainly the methylmercury cysteine complexes $\left(\mathrm{CH}_{3} \mathrm{Hg}\right.$-Cys) [11].

- Facilitated diffusion [9].

- Active transport [12].

- Amino acid transporters, the MeHg-Cys pass through epithelial cells by L-type transporters (LAT) that are energy consumers. Beside the organic anionic transporters (OAT) [5].

The specific absorption mechanisms in different body tissues can be summarized:

The gastrointestinal enterocytes (GIE): The inorganic mercury may be transported by simple passive and active diffusion [10] [51] [52], also as the diet rich in amino acids, and the mercuric ion has high affinity to sulfhydryl terminals making amino acid complexes, that can be mediated by organic transporters [5]. Even though the methylmercury transportation is more efficient, thus more dangerous. The methylmercury bind to the sulfurous part of glutathione (GSH) inside the lumen forming methylmercury glutathione complex (MeHg-SG), that will be transported by $\gamma$-glutamyltransferase (GGT) and cysteinylglycinase (CGase) [53], they are members of OAT found several cell membranes including the gut lumen, then $\left(\mathrm{CH}_{3} \mathrm{Hg}-\mathrm{SG}\right)$ complex pass into the circulation [9]. While in the Blood brain barrier (BBB): The transportable form is (MeHg-S-G) via LAT 
system [4]. In the Kidney, mercury accumulates in the cortex and outer medulla of the kidney by $50 \%$ of exposure [54]. This took place by OAT ( $\gamma$-glutamyltransferase and cysteinylglycinase). While $\mathrm{MeHg}$ transported after conjugation to the sulfur of the glutathione to form $\mathrm{CH}_{3} \mathrm{Hg}-\mathrm{S}-\mathrm{G}$ and to the cysteine molecule $\mathrm{CH}_{3} \mathrm{Hg}$-S-Cys [53]. The laters are considered the most transportable forms of organic mercury by the OAT [5]. The Liver absorbs methylmercury molecules via the circulation, that will reach the bile as $\mathrm{CH}_{3} \mathrm{Hg}-\mathrm{S}-\mathrm{G}$, this part will be reabsorbed by the enterocytes making the MeHg enterohepatic cycle [5], but most of it will be excreted with feces (Clarkson et al., 2007).

Placenta: The organic MeHg compounds are transported through the placenta as cysteine conjugates $\left(\mathrm{CH}_{3} \mathrm{Hg}\right.$-S-Cys) mainly by the LAT members [5] [55].

Toxicity mechanisms: Mercury has a major role to induce oxidative stress by inducing several protein disturbances at different levels including; starting with mitochondrial dysfunction [56] (Berntssen et al., 2003), that increase the hydrogen peroxides and lipid peroxidation [57].

The high affinity of methylmercury to bind to the sulfhydryl terminal of the proteins, results in block of active sites of functional proteins, transporters, enzymes, receptors, and others [7].

At the same time, mercury causes reduction in the defense mechanisms, by induction of apoptosis in human T cells and monocytes [58]. Also, by binding to the GSH molecules, and lipid peroxidation. This will result in a rise risk of cardiovascular risk factors, increase LDL-C molecules, dysfunctional HDL-C [59], beta cell dysfunction and insulin resistance [57] [60]. This has a negative effect of increasing the blood pressure, by listening to the nitric oxide (NO), and angiotensin converting enzymes activity (ACE) [7]. Also, it has a role of obesity related problems thru the interruption of pre-adipocyte differentiation [58].

\section{Factors Affect the Hg Compounds Bioaccessibility}

The term bioaccessibility is referred to the part of ingested nutrient that is solubilized into the gastrointestinal tract become available for intestinal absorption, any factor affects the bioaccessibility well change the amount of $\mathrm{Hg}$ absorbed to blood and other body organs [41] [61] [62].

Cooking effect: Cooking causes increase in the concentration of the metal in the food portion. Due to loss of fluids relative to the fresh food. Cooking leads to listening the bioaccessibility of $\mathrm{Hg}$ ordered in descending manner as (highest concentration of raw food, then steamed or boiled, next become the grilled, and finally fried with at last) by $(26 \%-85 \%)$ lower bioaccessibility [13] [14] [15]. This reduction of bio-accessibility was proposed by Afonso et al, (2015) [63] to the protein denaturation by cooking, that disrupts the tertiary and quaternary structure. That results in decrease protease action, so that less Hg bioaccessibility, as tuna consider important source of $\mathrm{Hg}$ in human diet [13]. Ouédraogo et al., (2011) proposed reduction of tuna $\mathrm{Hg}$ content by $40 \%$. The heat used in cooking and canning process mostly reduces the Hg bioaccessibility [14] [63]. 
Selenium: It's is essential metal for several physiological processes, the selenocystein and selenomethionine are the main selenoproteins, that incorporate in the redox enzymes including; antioxidant glutathione peroxidase (GSH-Px), beside the selenoenzymes selenoenzymes; iodothyronine deiodinases, 5,5'-monodeiodination that activate the thyroid hormone, also the thioredoxin reductases [22] [23].

Selenium is known as natural protective agents, against mercury induced toxicity. Due to its ability to counteracts the adverse influences of methyl mercury, by the antagonism effect to $\mathrm{Hg}$ and other heavy metals when they administered simultaneously [21]. The seleno-cysteine acts as ROS scavenger making detoxifying effect [21] [22] [23]. At the same time, mercury selenium insoluble complex well is formed "bis-methylmercuric selenide" (BMS), this compound is considered inert, high molecular weight, large complex, stable, non-diffusible, has long retention time in the blood and low accumulation in the kidneys and liver [64], that will reflect positively on methyl mercury toxicity.

Glutathione: Glutathione is a tripeptide ( $\gamma$-glutamylcysteinyl-glycine), synthesized in the liver, provides about $(30 \%-40 \%)$ of the plasma antioxidant capacity, and is the most potent intracellular and mitochondrial antioxidant for protecting against oxidative stress, inflammation, and cardiovascular diseases [19] [21] [24].

Mercury binds to glutathione via the sulfhydryl terminal as in a comparable form of the oxidized glutathione (GS-SG), so that transport freely via glutathione endogenous carrier across the liver cell membrane into bile [4]. Then it will be hydrolyzed by enzymes ( $\gamma$-glutamyl transpeptidase and dipeptidase) to glutathione constituents and $\mathrm{CH}_{3}-\mathrm{Hg}$-Cys complex, that well be reabsorbed to the circulation, and the $\mathrm{CH}_{3}-\mathrm{Hg}$ form the glutathione complex in the liver, and reabsorption by the gallbladder making the enterhaepatic cycle [4] [7] [8].

High fat diet: Højbjerg, et al., (1992) in animal experiment, demonstrate that the high fat diet (50\%) results in lower absorption of methylmercury and mercuric chloride than the low fat diet $(5.0 \%)$, it was explained by increase satiety and lower food intake, on the other hand, the high fat diet effect of saponification [18].

At the same time, the type of the fat used in the diet cause variations for mercury retained in the body. The coconut oil retained higher amount of than the cod liver fat type. Even though the higher content of cod liver oil in the diet results in lower retention of methyl mercury and mercury chloride than the lower content diets [16] [17] [18].

Modulation of mercury toxicity by fish oil took place by the Inuit people; fish oil is known to contain substantial amounts of omega-3 alpha-linoleic acid [65]. On the other hand, lower incidence of mortality in people who used to consume fish based diets, or their oil supplements regardless the level of contamination [66].

Insignificant but lower whole body total mercury retention and higher fecal excretion between the fish based diets and lard diets, which reflect the protective 
role of fish based diets methylmercury toxicity modulation [17].

Omega-3 PUFA: Appropriate amounts of omega-3 polyunsaturated fatty acids attained mainly from reasonable consumption of fish diets, this will also provide appreciable amounts of selenium. The $\mathrm{n}-3$ fatty acids well antagonize some of the adverse effects of this mercury exposure [19] Genchi et al., 2017), The n-3 long chain poly unsaturated fatty acids (n-LCPUFA) contain two important essential components (eicosapentaenoic-EPA and docosahexaenoic-DHA). Several researches approve the antioxidant effect of $\mathrm{n}-3$ in fighting the reactive oxygen species, lipid peroxides, free radicals, and scavenge the superoxide onion [20]. These processes alienate any oxidation effect discussed above may produce by the mercury exposure.

Dietary Fibers: No significant decrease in Hg bioaccessibility observed for mackerel and shark after addition of cornstarch. For tuna, a decrease of up to $20 \%$ of $\mathrm{Hg}$ bioaccessibility was reported after the addition of $50 \mathrm{mg}$ of cornstarch, but no further decrease occurred after the addition of more cornstarch [15]. While Shim et al. (2009) [16] evidenced that the presence of insoluble fibers, such as those from wheat, decreases $\mathrm{Hg}$ bioaccessibility, since these compounds can bond and diminish $\mathrm{Hg}$ solubility. This fact might explain the low $\mathrm{Hg}$ bioaccessibility in fried black scabbard fish, as wheat flour added during the culinary preparation [16].

The dietary fibers may have adsorbent effects that may reduce the metal bioaccessibility in contaminated food [26], due to their non-toxic and non-degradable nature [16]. This theory was investigated by [25], by applying a natural dietary factor to chelate the heavy metals in the contaminated food. They found a reduction of mercury bioaccessibility by $(34 \%-85 \%)$ in a dose dependent manner, when used the cassava pulp tubers, which is rich starch $(60 \%)$ and rich fiber (30\%) tubers [25].

On the other hand, wheat bran had a great effect on mercury binding capacity by $(72 \%-84 \%)$ much more than oat bran and psyllium, this due to higher content of insoluble fiber content in the wheat brane than the others [16]. Consistent results with Rowland et al. (1986) [27], he found that wheat bran consumption with the mercury food resulted in increased fecal excretion, and reduce the methyl-mercury level in the blood and brain of experimental animals by (10\% 30\%) [27].

Garlic and Onion: The garlic (Alium sativum) contains organosulfur compounds (OSC) as a cysteine derivative. The garlic exhibits a numerous beneficial biological activities, by having oxidative stress reduction and apoptotic effects [67] [68]. It was believed that garlic has metal binding capacity or chelating agents which can increase mercury excretion [35] [69]. This may be explaind to the high affinity of the mercuric compounds to the sulfur compounds [7], so by binding to $-\mathrm{SH}$ terminal in the chelating agent provide protection to the active site of functional proteins [35] [36].

The same mechanism proposed by [33], that the binding of the $\mathrm{Hg}$ to the 
sulfhydryl groups in the cell wall of the green onion, and react to reduce Se availability and make the Se-Hg complex [32] [33] [34].

Ethanol role in mercury retention: Ethanol consumption associated with lower retention of mercury in the serum and the erythrocytes in a dose dependent manner [37], both human and animal experiments confirm the same results [38] [39].

One of the proposed mechanisms for ethanol role is the inhibition of mercury oxidation in the presence of ethanol even at very low concentration $(0.2 \%)$, beside the mercury may mobilize and reduce in the accumulated inorganic mercury in the tissues [39]. Although taking into consideration the diuretic effect of the ethanol consumption that results in excretion and mobilization of body mercury [37]. Sumathi and Chritinal, (2015) [70] revealed in their research the normalization effect of ethanol derivatives against histopathological alteration of the mercury induced toxicity.

Gut Flora: Microbes have been known to modulate a wide range of heavy metals toxicity including $\mathrm{MeHg}$, the remediation of contaminates environments using microbes are an effective process [30] [71] [72] [73] [74].

The demethylation process is accomplished via two steps: first the reduction of $\mathrm{MeHg}$ to produce $\mathrm{Hg}^{0}$ and $\mathrm{CH}_{4}$, second the oxidation that results with $\left(\mathrm{Hg}^{+2}+\right.$ $\mathrm{CO}_{2}$ ) [28] [29]. Other several detoxification mechanisms were proposed that decrease mercury bioaccessibility, they comprise mercury resistant gram positive and gram negative bacteria including the biosorption, biotransformation, bioaccumulation, and biovolatilization, these organisms contain large surface to volume with active cell wall, the functional phosphate, sulfonate, hydroxyl, carboxyl and amide groups act as chemisorption sites [75].

Five strains from Enterobacter, Bacillus, and Pseudomonas bacteria were isolated and demonstrated to be effective in adsorption and accumulation of $99 \%$ of mercury from the surrounds [73], beside commensal methanogenic archaea bacterial types contain gene clusters required for mercury metabolism was isolated from human feces [30] [31].

In vitro experiments, mice showed increase methyl mercury fecal excretion with prolonged antibiotic treatments, due to demethylation of the methylmercury to the inorganic mercury, which is less absorbable form by the gut [27]. Comparable results from experiment constructed on neonatal rats with sterile gut, compared to older weaned rats, after giving oral dose of methylmercury, longer time of suckling rats was needed to eliminate the mercury dose [27].

Lower blood mercury concentration was in the Tanzanian pregnant women who used to consume yoghurt (contain probiotic Lactobacillus rhamnosus GR-1), when compared to control [76].

Fruit: As fresh fruits very rich in mineral, antioxidents, vitamins especially vitamin $\mathrm{E}$ and vitamin $\mathrm{C}$, beside substantial amounts of the fibers, that may modulate the mercury absorption. Several studies took place in the Brazilian region, due to the highest level of blood mercury concentration among the Ama- 
zon population, owed to large dependence on fish diet [41] [42] [43].

Inverse relationship was found between the fresh fruit intake in the Amazon region and blood mercury concentrations [41] [77], the fruit was the only material that modulates the mercury exposure and blood concentration among all the dietary items studied [78].

In addition, Jacob and colleague [40], demonstrated the protective effect of the bioactive flavonoid (fisetin), which is a coloring polyphenols found in many fruits such as strawberries and grapes. Fisetin protects the offspring after maternal exposure to MeHg exposure, by decreasing the level of oxidative stress biomarkers [40].

Tea and coffee: Flavonoids in black tea is type of polyphenols, known by its chelating capacity for the redox active metals such as non-heme iron that may result in anemia [78]. The same scenario applied to the inorganic mercury. As well, tea reveals diuretic effect, that participates in $\mathrm{Hg}$ excretion by urine, and mobilization of it from liver and kidney [14] [15] [45], result in significant reduction of blood mercury level.

Ouédraogo et al., (2011) [15] reported a reduction of $\mathrm{Hg}$ bioaccessibility by more than $50 \%$ after addition of $40 \mathrm{mg}$ of green or black tea. However $14 \mathrm{He}$ and Wang, (2011) reported a reduction of the bioaccessibility with addition of green and black tea extract, with greater reduction in the green tea by more than $72 \%$ in different fish types. They proposed the presence of the flavonoids polyphenols beside the catechins and the flavins, these compounds act as good natural scavengers of metals [14] [15].

Controversy results obtained by Janle et al., (2015) [44], were surprised to found significant increase of mercury bioavailability rather than reduction, by the addition of green tea after administration of fish meat as bolus to experimental rats [14]. Similar results attained by Canuel et al., (2006) after three days of 6 cups tea consumption and $150 \mathrm{~g}$ fish meals for 6 times, to consumers and compare them with non-tea drinkers with fish meals of Canadian aboriginal populations, the results showed $40 \%$ higher than those consume fish without tea [45]. The hypothesized mechanism by Canuel the amplification of mercury due to enterohepatic circulation and release of $\mathrm{Hg}$ from the liver stores, and secretion into bile as MeHg-G complex, that well be reabsorbed by the intestine [45].

Few studies investigate the coffee consumption effects on mercury bioavailability, Ouédraogo revealed that the co-ingestion of coffee had a lesser effect on $\mathrm{Hg}$ bioavailability, leaving about $50 \%$ of $\mathrm{Hg}$ bioaccessible, after the addition of $40 \mathrm{mg}$ instant coffee [15] [16].

\section{Summary}

Toxic effect of the mercury documented in several historical accidents that revealed by neurological symptoms, the cardio metabolic syndrome, liver and renal diseases via the oxidative stress mechanisms, due to the strong ability of the mercuric compounds to bind to the sulfhydryl terminal of vital proteins and en- 
zymes. The diet, especially the fish based ones accumulates significant amounts of the methylmercury, which threaten the human body.

Fortunately, the diet complexity results in decreasing the mercuric bioaccessibility within the human gut, although the gut microflora plays a crucial role for decreasing the available amounts of mercury in the gut.

In vivo studies, detect the cooking effect, the high fat content diet, presence of divalent cations like selenium, dietary fibers, protein content that affect the glutathione concentration, the organosulfur compounds present in the garlic and onion, ethanol consumption, antioxidants and fruits intake, beside the gut microbiota that plays an appreciable role in the detoxification of mercuric compounds.

\section{Conflicts of Interest}

The author declares no conflicts of interest regarding the publication of this paper.

\section{References}

[1] Zárate, R., El Jaber-Vazdekis, N., Tejera, N., Pérez, J.A. and Rodríguez, C. (2017) Significance of Long Chain Polyunsaturated Fatty Acids in Human Health. Clinical and Translational Medicine, 6, 25. https://doi.org/10.1186/s40169-017-0153-6

[2] Mark, C. (2011) Role of Mercury Toxicity in Hypertension, Cardiovascular Disease, and Stroke. Journal of Clinical Hypertension, 13, 621-627. https://doi.org/10.1111/j.1751-7176.2011.00489.x

[3] Ahmad, M.N. and Abdullah, N. (2019) Fish and Cardiometabolic Concerns: A Link through Lead and Mercury. International Journal of Contemporary Medical Research, 9, 64-73.

[4] Clarkson, T.W., Vyas, J.B. and Ballatori, N. (2007) Mechanisms of Mercury Disposition in the Body. American Journal of Industrial Medicine, 50, 757-764. https://doi.org/10.1002/ajim.20476

[5] Bridges, C. and Zalups, R. (2010) Transport of Inorganic Mercury and Methylmercury in Target Tissues and Organs. Journal of Toxicology and Environmental Health, Part B: Critical Reviews, 13, 385-410. https://doi.org/10.1080/10937401003673750

[6] Rizzetti, D., da Silva, T., Escobar, A., Piagette, J., Peçanha, F., Vassallo, D., et al. (2018) Mercury-Induced Vascular Dysfunction Is Mediated by Angiotensin II AT-1 Receptor Upregulation. Environmental Research, 162, 287-296. https://doi.org/10.1016/j.envres.2018.01.026

[7] Sun, L., Gao, S., Wang, K., Xu, J., Sanz-Fernandez, M., Baumgard, L.H. and Bu, D. (2018) Effects of Source on Bioavailability of Selenium, Antioxidant Status, and Performance in Lactating Dairy Cows during Oxidative Stress-Inducing Conditions. Journal of Dairy Science, 102, 311-319. https://doi.org/10.3168/jds.2018-14974

[8] Dutczak, W.J. and Ballatori, N. (1992) Gammaglutamyltransferase-Dependent Biliary-Hepatic Recycling of Methyl Mercury in the Guinea Pig. Journal of Pharmacology and Experimental Therapeutics, 262, 619-623.

[9] Leaner, J.J. and Mason, R.P. (2002) Methylmercury Accumulation and Fluxes across the Intestine of Channel Catfish, Lctalurus punctatus. Comparative Biochemistry 
and Physiology-Part C: Toxicology, 132, 247-259.

https://doi.org/10.1016/S1532-0456(02)00072-8

[10] Hoyle, I. and Handy, R. (2005) Dose-Dependent Inorganic Mercury Absorption by Isolated Perfused Intestine of Rainbow Trout, Oncorhynchus mykiss, Involves Both Amiloride-Sensitive and Energy-Dependent Pathways. Aquatic Toxicology, 72, 147-159. https://doi.org/10.1016/j.aquatox.2004.11.015

[11] Lawson, N.M. and Mason, R.P. (1998) Accumulation of Mercury in Estuarine Food Chains. Biogeochemistry, 40, 235-247. https://doi.org/10.1023/A:1005959211768

[12] Fujiyama, J., Hirayama, K. and Yasutake, A. (1994) Mechanism of Methylmercury Efflux from Cultured Astrocytes. Biochemical Pharmacology, 29, 1525-1530. https://doi.org/10.1016/0006-2952(94)90527-4

[13] Bradley, M.A., Barst, B.D. and Basu, N.A. (2017) Review of Mercury Bioavailability in Humans and Fish. International Journal of Environmental Research and Public Health, 14, 169. https://doi.org/10.3390/ijerph14020169

[14] He, M. and Wang, W.X. (2011) Factors Affecting the Bioaccessibility of Methylmercury in Several Marine Fish Species. Journal of Agricultural and Food Chemistry, 59, 7155-7162. https://doi.org/10.1021/jf201424g

[15] Ouédraogo, O. and Amyot, M. (2011) Effects of Various Cooking Methods and Food Components on Bioaccessibility of Mercury from Fish. Environmental Research, 111, 1064-1069. https://doi.org/10.1016/j.envres.2011.09.018

[16] Shim, S.M., Ferruzzi, M.G., Kim, Y.C., Janle, E.M. and Santerre, C.R. (2009) Impact of Phytochemical-Rich Foods on Bioaccessibility of Mercury from Fish. Food Chemistry, 112, 46-50. https://doi.org/10.1016/j.foodchem.2008.05.030

[17] Jin, X., Lok, E., Bondy, G., Caldwell, D., Mueller, R., Kapal, K., et al (2007) Modulating Effects of Dietary Fats on Methylmercury Toxicity and Distribution in Rats. Toxicology, 230, 22-44. https://doi.org/10.1016/j.tox.2006.10.023

[18] Højbjerg, S., Nielsen, J. and Andersen, O. (1992) Effects of Dietary Lipids on Whole-Body Retention and Organ Distribution of Organic and Inorganic Mercury in Mice. Food and Chemical Toxicology, 30, 703-708.

https://doi.org/10.1016/0278-6915(92)90166-I

[19] Genchi, G., Sinicropi, M., Carocci, A., Lauria, G. and Catalano, A. (2017) Mercury Exposure and Heart Diseases. International Journal of Environmental Research and Public Health, 14, 74. https://doi.org/10.3390/ijerph14010074

[20] Giordano, E. and Visioli, F. (2014) Long-Chain Omega 3 Fatty Acids: Molecular Bases of Potential Antioxidant Actions. Literature Review in Prostaglandins Leukotrienes and Essential Fatty Acids, 90, 1-4. https://doi.org/10.1016/j.plefa.2013.11.002

[21] Branco, V., Coppo, L., Solá, S., Lu, J., Rodrigues, C., Holmgren, A. and Carvalho, C. (2017) Impaired Cross-Talk between the Thioredoxin and Glutathione Systems Is Related to ASK-1 Mediated Apoptosis in Neuronal Cells Exposed to Mercury. Redox Biology, 13, 278-287. https://doi.org/10.1016/j.redox.2017.05.024

[22] Battin, E.E. and Brumaghim, J.L. (2009) Antioxidant Activity of Sulfur and Selenium: A Review of Reactive Oxygen Species Scavenging, Glutathione Peroxidase, and Metal-Binding Antioxidant Mechanisms. Cell Biochemistry and Biophysics, 55, 1-23. https://doi.org/10.1007/s12013-009-9054-7

[23] Suzuki, K.T. and Ogra, Y. (2002) Metabolic Pathway for Selenium in the Body: Speciation by HPLC-ICP MS with Enriched Se. Food Additives \& Contaminants, 19, 974-983. https://doi.org/10.1080/02652030210153578

[24] Martinez, C.S., Peçanha, F.M., Brum, D.S., Santos, F.W., Franco, J.L., Zemolin, A.P., 
et al. (2016) Reproductive Dysfunction after Mercury Exposure at Low Levels: Evidence for a Role of Glutathione Peroxidase (GPx) 1 and GPx4 in Male Rats. Reproduction, Fertility and Development, 29, 1803-1812.

https://doi.org/10.1071/RD16310

[25] Kachenpukdee, N., Santerre, C.R., Ferruzzi, M.G. and Oonsivilai, R. (2016) Modified Dietary Fiber from Cassava Pulp and Assessment of Mercury Bioaccessibility and Intestinal Uptake Using an in Vitro Digestion/Caco-2 Model System. Journal of Food Science, 81, T1854-T1863. https://doi.org/10.1111/1750-3841.13336

[26] Coşkun, R., Soykan, C. and Saçak, M. (2006) Removal of Some Heavy Metal Ions from Aqueous Solution by Adsorption Using Poly(Ethylene Terephthalate)-g-Itaconic Acid/Acrylamide Fiber. Reactive and Functional Polymers, 66, 599-608.

https://doi.org/10.1016/j.reactfunctpolym.2005.10.012

[27] Rowland, I.R. (1988) Factors Affecting Metabolic Activity of the Intestinal Microflora. Drug Metabolism Reviews, 19, 243-261. https://doi.org/10.3109/03602538808994135

[28] Kronberg, R.M., Schaefer, J.K., Björn, E. and Skyllberg, U. (2018) Mechanisms of Methyl Mercury Net Degradation in Alder Swamps: The Role of Methanogens and Abiotic Processes. Environmental Science \& Technology Letters, 5, 220-225. https://doi.org/10.1021/acs.estlett.8b00081

[29] Martín-Díaz, M.L., Jiménez-Tenorio, N., Sales, D. and Delvalls, T.A. (2008) Accumulation and Histopathological Damage in the Clam Ruditapes philippinarum and the Crab Carcinus maenas to Assess Sediment Toxicity in Spanish Ports. Chemosphere, 71, 1916-1927. https://doi.org/10.1016/j.chemosphere.2008.01.022

[30] Smith, S.D., Bridou, R., Johs, A., Parks, J.M., Elias, D.A. and Hurt, R.A. (2015) Site Directed Mutagenesis of $\mathrm{HgcA}$ and $\mathrm{HgcB}$ Reveals Amino Acid Residues Important for Mercury Methylation. Applied and Environmental Microbiology, 81, 3205-3217. https://doi.org/10.1128/AEM.00217-15

[31] Dridi, B., Fardeau, M.L., Ollivier, B., Raoult, D. and Drancourt, M. (2012) Methanomassiliicoccus luminyensis gen. nov., sp. nov., a Methanogenic Archaeon Isolated from Human Faeces. International Journal of Systematic and Evolutionary Microbiology, 62, 1902-1907. https://doi.org/10.1099/ijs.0.033712-0

[32] Zhao, J., Gao, Y., Li, Y.F., Hu, Y., Peng, X., Dong, Y., et al. (2013) Selenium Inhibits the Phytotoxicity of Mercury in Garlic (Allium sativum). Environmental Research, 125, 75-81. https://doi.org/10.1016/j.envres.2013.01.010

[33] McNear, D., Afton, S. and Caruso, J. (2012) Exploring the Structural Basis for Selenium/Mercury Antagonism in Allium fistulosum. Metallomics, 4, 267-276. https://doi.org/10.1039/c2mt00158f

[34] NRC: Committee on the Toxicological Effects of Methylmercury (2000) Toxicological Effects of Methylmercury. National Academic Press, Washington DC.

[35] Cha, C. (1987) A Study on the Effect of Garlic to the Heavy Metal Poisoning of Rat. Journal of Korean Medical Science, 2, 213-233.

https://doi.org/10.3346/jkms.1987.2.4.213

[36] Eom, Y., Won, J.H., Ryu, J.Y. and Lee, T.G. (2011) Biosorption of Mercury (II) Ions from Aqueous Solution by Garlic (Allium sativum L.) Powder. Korean Journal of Chemical Engineering, 28, 1439-1443. https://doi.org/10.1007/s11814-010-0514-y

[37] Martin, M.D. (2004) The Inhibition of Mercury Absorption by Dietary Ethanol in Humans: Cross-Sectional and Case-Control Studies. Occupational and Environmental Medicine, 61, e8. https://doi.org/10.1136/oem.2003.007542

[38] Grandjean, P., Weihe, P., Jørgensen, P.J., Clarkson, T., Cernichiari, E. and Viderø, 
T. (1992) Impact of Maternal Seafood Diet on Fetal Exposure to Mercury, Selenium, and Lead. Archives of Environmental Health, 47, 185-195.

https://doi.org/10.1080/00039896.1992.9938348

[39] Magos, L., Clarkson, T.W. and Greenwood, M.R. (1973) The Depression of Pulmonary Retention of Mercury Vapor by Ethanol: Identification of the Site of Action. Toxicology and Applied Pharmacology, 26, 180-183. https://doi.org/10.1016/0041-008X(73)90251-2

[40] Jacob, S. and Thangarajan, S. (2018) Fisetin Impedes Developmental Methylmercury Neurotoxicity via Downregulating Apoptotic Signalling Pathway and Upregulating Rho GTPase Signalling Pathway in Hippocampus of F1 Generation Rats. International Journal of Developmental Neuroscience, 69, 88-96.

https://doi.org/10.1016/j.ijdevneu.2018.07.002

[41] Passos, C.J., Da Silva, D.S., Lemire, M., Fillion, M., Guimarães, J.R., Lucotte, M. and Mergler, D. (2007) Daily Mercury Intake in Fish-Eating Populations in the Brazilian Amazon. Journal of Exposure Science and Environmental Epidemiology, 18, 76-87. https://doi.org/10.1038/sj.jes.7500599

[42] Bastos, W.R., Gomes, J.P., Oliveira, R.C., Almeida, R., Nascimento, E.L., Bernardi, J.V., et al (2006) Mercury in the Environment and Riverside Population in the Madeira River Basin, Amazon, Brazil. Science of the Total Environment, 368, 344-351. https://doi.org/10.1016/j.scitotenv.2005.09.048

[43] Pinheiro, M.C., Oikawa, T., Vieira, J.F., Gomes, M.S., Guimarates, G.A., Crespo-Lopez, M.E., et al. (2006) Comparative Study of Human Exposure to Mercury in Riverside Communities in the Amazon Region. Brazilian Journal of Medical and Biological Research, 39, 411-414. https://doi.org/10.1590/S0100-879X2006000300012

[44] Janle, E.M., Freiser, H., Manganais, C., Chen, T.Y., Craig, B.A. and Santerre, C.R. (2015) Green Tea Increases the Concentration of Total Mercury in the Blood of Rats Following an Oral Fish Tissue Bolus. BioMed Research International, 2015, Article ID: 320936. https://doi.org/10.1155/2015/320936

[45] Canuel, R., de Grosbois, S.B., Lucotte, M., Atikessé, L., Larose, C. and Rheault, I. (2006) New Evidence on the Effects of Tea on Mercury Metabolism in Humans. Archives of Environmental \& Occupational Health, 61, 232-238. https://doi.org/10.3200/AEOH.61.5.232-238

[46] Duan, Q. and Portal, J. (2007) Scientific Studies of High Level of Mercury in Qin Shihuangdi's Tomb, in the First Emperor: China's Terracotta Army. Harvard University Press, Cambridge, 204-207.

[47] Shimohata, T., Hirota, K., Takahashi, H. and Nishizawa, M. (2015) Clinical Aspects of the Nigata Minamata Disease. Brain and Nerve, 65, 31-38.

[48] Jackson, A. (2018) Chronic Neurological Disease Due to Methylmercury Poisoning. Canadian Journal of Neurological Sciences, 45, 620-623.

https://doi.org/10.1017/cjn.2018.323

[49] Matsumoto, M. and Liu, H. (2020) Mercury Speciation and Remediation Strategies at a Historically Elemental Mercury Spilled Site. Journal of Hazardous Materials, 384, Article ID: 121351. https://doi.org/10.1016/j.jhazmat.2019.121351

[50] Xu, H., Ma, Y., Huang, W., Hong, Q., Liao, Y., Qu, Z. and Yan, N. (2020) Enhancing the Catalytic Oxidation of Elemental Mercury and Suppressing Sulfur-Toxic Adsorption Sites from $\mathrm{SO}_{2}$-Containing Gas in $\mathrm{Mn}_{-} \mathrm{SnS}_{2}$. Journal of Hazardous Materials, 392, Article ID: 122230. https://doi.org/10.1016/j.jhazmat.2020.122230

[51] Andres, S., Laporte, J. and Mason, R. (2002) Mercury Accumulation and Flux across 
the Gills and the Intestine of the Blue Crab (Callinectes sapidus). Aquatic Toxicology, 56, 303-320. https://doi.org/10.1016/S0166-445X(01)00228-4

[52] Laporte, J., Andres, S. and Mason, P. (2002) Effect of Ligands and Other Metals on the Uptake of Mercury and Methylmercury across the Gills and the Intestine of the Blue Crab (Callinectes sapidus). Comparative Biochemistry and Physiology Part $C$, 131, 185-196. https://doi.org/10.1016/S1532-0456(01)00289-7

[53] Zalups, R.K. (2000) Molecular Interactions with Mercury in the Kidney. Pharmacological Reviews, 52, 113-143.

[54] Zalups, R.K. (1993) Early Aspects of the Intrarenal Distribution of Mercury after the Intravenous Administration of Mercuric Chloride. Toxicology, 79, 215-228. https://doi.org/10.1016/0300-483X(93)90213-C

[55] Straka, E., Ellinger, I., Balthasar, C., Scheinast, M., Schatz, J., Szattler, T., et al (2016) Mercury Toxicokinetics of the Healthy Human Term Placenta Involve Amino Acid Transporters and ABC Transporters. Toxicology, 340, 34-42. https://doi.org/10.1016/j.tox.2015.12.005

[56] Berntssen, M., Aatland, A. and Handy, R. (2003) Chronic Dietary Mercury Exposure Causes Oxidative Stress, Brain Lesions, and Altered Behaviour in Atlantic Salmon (Salmo salar) Parr. Aquatic Toxicology, 65, 55-72. https://doi.org/10.1016/S0166-445X(03)00104-8

[57] Chen, H.C., Tsai, K.S., Yen, C.C., Yang, C.Y., et al. (2006), Methylmercury Induces Pancreatic Beta-Cell Apoptosis and Dysfunction. Chemical Research in Toxicology, 19, 1080-1085. https://doi.org/10.1021/tx0600705

[58] Kim, S. and Sharma, R. (2004) Mercury-Induced Apoptosis and Necrosis in Murine Macrophages: Role of Calcium-Induced Reactive Oxygen Species and p38 Mitogen-Activated Protein Kinase Signaling. Toxicology and Applied Pharmacology, 196, 47-57. https://doi.org/10.1016/j.taap.2003.11.020

[59] Takahashi, T. and Shimohat, T. (2019) Vascular Dysfunction Induced by Mercury Exposure. International Journal of Molecular Sciences, 20, 2435. https://doi.org/10.3390/ijms20102435

[60] Shenker, B., Maserejian, N., Zhang, A. and McKinlay, S. (2008) Immune Function Effects of Dental Amalgam in Children: A Randomized Clinical Trial. Journal of the American Dental Association, 139, 1496-1505. https://doi.org/10.14219/jada.archive.2008.0076

[61] Oomen, A., Tolls, J., Sips, A. and Hoopm, V. (2003) Lead Speciation in Artificial Human Digestive Fluid. Archives of Environmental Contamination and Toxicology, 44, 107-115. https://doi.org/10.1007/s00244-002-1225-0

[62] Ruby, M.V., Schoof, R., Brattin, W., Goldade, P.G. and Harnoise, M. (1999) Advances in Evaluating the Oral Bioavailability of Inorganics in Soil for Use in Human Health Risk Assessment. Environmental Science \& Technology, 33, 3697-3705. https://doi.org/10.1021/es990479z

[63] Afonso, C., Costa, S., Cardoso, C., Oliveira, R., Lourenco, H.M., Viula, A., et al. (2015) Benefits and Risks Associated with Consumption of Raw, Cooked, and Canned Tuna (Thunnus spp.) Based on the Bioaccessibility of Selenium and Methylmercury. Environmental Research, 143, 130-137. https://doi.org/10.1016/j.envres.2015.04.019

[64] Imura, N. and Naganuma, A. (1991) Possible Mechanism of Detoxifying Effect of Selenium on the Toxicity of Mercury Compounds. In: Suzuki, T., Imura, N. and Clarkson, T.W., Eds., Advances in Mercury Toxicology, Rochester Series on Environmental Toxicity, Springer, Boston, 275-288. 
https://doi.org/10.1007/978-1-4757-9071-9_17

[65] Tortosa-Caparrós, E., Navas-Carrillo, D., Marín, F. and Orenes-Piñero, E. (2016) Anti-Inflammatory Effects of Omega 3 and Omega 6 Polyunsaturated Fatty Acids in Cardiovascular Disease and Metabolic Syndrome. Critical Reviews in Food Science and Nutrition, 57, 3421-3429. https://doi.org/10.1080/10408398.2015.1126549

[66] Guallar, E., Sanz-Gallardo, I., Veer, P.V., Bode, P., Aro, A., Gomez-Aracena, J., et al. (2002) Mercury, Fish Oils, and the Risk of Myocardial Infarction. The New England Journal of Medicine, 347, 1747-1754. https://doi.org/10.1056/NEJMoa020157

[67] El-Shenawy, S. and Hassan, N. (2008) Comparative Evaluation of the Protective Effect of Selenium and Garlic against Liver and Kidney Damage Induced by Mercury Chloride in the Rats. Pharmacological Reports, 60, 199-208.

http://if-pan.krakow.pl/pjp/pdf/2008/2

[68] Belloir, C., Singh, V., Daurat, C., Siess, M.H. and Le Bon, A.M. (2006) Protective Effects of Garlic Sulfur Compounds against DNA Damage Induced by Direct- and Indirect-Acting Genotoxic Agents in HepG2 Cells. Food and Chemical Toxicology, 44, 827-834. https://doi.org/10.1016/j.fct.2005.11.005

[69] Nwokocha, C.R., Owu, D.U., Nwokocha, M.I., Ufear, C.S. and Iwuala, M.O. (2012) Comparative Study on the Efficacy of Allium sativum (Garlic) in Reducing Some Heavy Metal Accumulation in Liver of Wistar Rats. Food and Chemical Toxicology, 50, 222-226. https://doi.org/10.1016/j.fct.2011.11.003

[70] Sumathi, T. and Christinal, J. (2015) Neuroprotective Effect of Portulaca oleracea Ethanolic Extract Ameliorates Methylmercury Induced Cognitive Dysfunction and Oxidative Stress in Cerebellum and Cortex of Rat Brain. Biological Trace Element Research, 172, 155-165. https://doi.org/10.1007/s12011-015-0546-6

[71] Rothenberg, Y., Keiserb, S., Ajamic, N., Wongc, M., Gesellc, J., Petrosinoc, F., et al. (2006) The Role of Gut Microbiota in Fetal Methylmercury Exposure: Insights from a Pilot Study. Toxicology Letters, 242, 60-67. https://doi.org/10.1016/j.toxlet.2015.11.022

[72] Parks, J.M., Johs, A., Podar, M., Bridou, R., Hurt, R.A., Smith, S.D., Tomanicek, S.J., et al. (2013) The Genetic Basis for Bacterial Mercury Methylation. Science, 339, 1332-1335. https://doi.org/10.1126/science.1230667

[73] Gilmour, C.C., Podar, M., Bullock, A.L., Graham, A.M., Brown, S.D., Somenahally, A.C., et al (2013) Mercury Methylation by Novel Microorganisms from New Environments. Environmental Science \& Technology, 47, 11810-11820. https://doi.org/10.1021/es403075t

[74] Liard, B.D., Shade, C., Gantner, N., Man Chan, H. and Siciliano, S.D. (2009) Bioaccessibility of Mercury from Traditional Northern Country Foods Measured Using an in Vitro Gastrointestinal Model Is Independent of Mercury Concentration. Science of the Total Environment, 407, 6003-6008.

https://doi.org/10.1016/j.scitotenv.2009.08.014

[75] Vijayaraghavan, K. and Yun, Y.S. (2008) Bacterial Biosorbents and Biosorption. Biotechnology Advances, 26, 266-291.

https://doi.org/10.1016/j.biotechadv.2008.02.002

[76] Bisanz, J.E., Enos, M.K., Mwanga, J.R., Changalucha, J., Burton, J.P., Gloor, G.B., et al. (2014) Randomized Open Label Pilot Study of the Influence of Probiotics and the Gut Microbiome on Toxic Metal Levels in Tanzanian Pregnant Women and School Children. mBio, 5, e01580-14. https://doi.org/10.1128/mBio.01580-14

[77] Passos, C.J. and Mergler, D. (2008) Socioeconomic Conditions and Mercury Exposure through Fish Consumption: A Case Study in Santarem, Para, Brazil. Revista- 
Saúde e MeioAmbiente, 6, 3-11.

[78] Nelson, M. and Poulter, J. (2004) Impact of Tea Drinking on Iron Status in the UK: A Review. Journal of Human Nutrition and Dietetics, 17, 43-54.

https://doi.org/10.1046/j.1365-277X.2003.00497.x 